\title{
A sensory sociology of the future: Affect, hope and inventive methodologies
}

\section{Contribution to Special Issue of The Sociological Review on 'Futures in}

\section{Question'.}

\begin{abstract}
The starting point for this article is that the future is difficult to research because of its intangibility. Drawing on recent work in visual and sensory sociology, affect, and time and futurity, I propose that sensory methodologies provide some ways of grasping, understanding, attuning and relating to the future. To develop this argument, I pay close attention to the Children of Unquiet (2013-14) project by artist Mikhail Karikis, and especially the film of the same name. This project involved Karikis working with local children to probe the possible futures of a site that was invested with hope and progress in the twentieth century, but has since been depopulated. In turning to an art project to consider the developments of a sensory sociology of the future, my intention is to examine the resonances between the project and some of the concerns of a sensory sociology of the future. In particular, I discuss the participation of children, and a conceptualization of hope as potentiality, open, affective and in the present. In conclusion, I explicate how the article seeks to contribute to a sensory sociology of the future, not by providing a blueprint for further work but rather by offering some indicative points and coordinates for this emerging field of research, including its involvement in creating conditions through which possible futures might be provoked or invented.
\end{abstract}


The issue of time, and particularly the future, has been a persistent, if somewhat overlooked, problem in sociology and the wider social sciences. However, the future is increasingly significant in how the contemporary Western world is organised, governed and experienced (Adams et al 2009, Massumi 2005, Anderson 2010, Adkins 2008, 2014, Coleman 2012), making it imperative for sociology to cultivate ways of grasping, understanding, attuning to and relating to the future. In this article, I consider the difficulty of researching the future; as a not-yet temporality, the future is slippery, ill defined, constantly moving and hence, intangible. Drawing on recent work in visual and sensory sociology, affect, and time and futurity, I propose that one way to research the future is through the development of a sensory sociology of the future, paying particular attention to the relevance of sensory methodologies.

To develop this argument, I focus on the Children of Unquiet (2013-14) project by artist Mikhail Karikis, and especially the film of the same name ${ }^{1}$. This project was based at the site of the first geothermal energy plant and the accompanying workers' villages in Tuscany, Italy. Itself a site of hope, ambition and progress in the early to mid twentieth century, automation of the factory at the end of that century led to the villages being depopulated, and the rise of a dominant local narrative of failure, resignation and despondency. This narrative is especially strong in relation to the children who grew up in or near the workers' villages, who were understood as having no future in the area. Karikis worked with some of these children to instigate a 'take-over' of the villages, 'asserting the younger generation's connection with the site of their childhood, challenging narratives of obligatory migration that dominate them, and evoking different possible, desired or imagined futures' (Karikis 2014b: 6). I think with and through the film and the project more broadly, to consider the 
salience and value of developing a sensory sociology to comprehend and perhaps provoke 'different possible, desired or imagined futures'.

In the article I have four aims. The first is to draw together some of the ways in which sociology and the social sciences have, (i) approached time and particularly futurity, (ii) theorized the affectivity and intangibility of the future, and (iii) indicated the potential of arts-based sensory methodologies for studying futurity. In this way, I draw attention to some of the existing sociological research that I characterise here as a 'sensory sociology of the future', to which I hope to contribute. The second aim is to develop this discussion in an analysis of the Children of Unquiet film. My focus on this film is not intended to be prescriptive, but rather to consider it as an example through which to examine what Mike Michael terms the 'common byways' (2012: 177) between some of the concerns of participatory arts projects and a sensory sociology of the future. My third aim is to explore the possible futures that are indicated in Children of Unquiet, paying particular attention to the participation of children, and to how the film operates affectively. The latter concern is explored through a discussion of the potentiality of hope (Muñoz 2009), and sound/sounding and politics (Oswell 2009). My fourth aim, discussed in the conclusion, is to explicate how the argument I make might contribute to a sensory sociology of the future, not by providing a blueprint for further work, but by offering some indicative points and coordinates for this emerging field of research. Of particular importance here, I suggest, is not only how a sensory sociology of the future might document the future, but also how it might be an interdisciplinary project involved in creating conditions through which possible futures might be provoked or invented. Throughout the paper is a concern with sociological research on futurity, the child and methodologies, 
hence my attempt to contribute towards a sensory sociology of the future. However, through its interest in interdisciplinary and its focus on an art project, it is worth noting that the argument developed here may intersect with moves in other social science fields, including geography (e.g. MacCormack 2014, Anderson, this volume) and anthropology (e.g. Pink 2006), and in visual studies and art.

\section{The intangibility of the future: Affect, sensory sociology and arts-based}

\section{methodologies}

While a wide range of methodologies and methods, and modes of analysis and interpretation, have been developed to study space, the same cannot be said to the same extent of time. As Barbara Adam points out, 'social scientists charged with the explanation of social life tend to take time for granted, leaving it unaddressed as an implicated rather than explicated feature of their theories and empirical studies' (2004: 3). In particular, research on the future has been 'neglected in sociological theory and research' (Mische 2009: 695). However, as this special issue demonstrates, there has recently been an increased interest in what Nik Brown and Mike Michael describe as an 'engage[ment] with the future as an analytical object, and not simply a neutral temporal space into which objective expectations can be projected' (2003: 4).

While this work demonstrates that a concern with the future is necessary, it also poses a number of difficulties. Dawn Lyon and Giulia Carabelli comment that while 'our orientations to the future matter a great deal for how we inhabit the present', '[t]he future eludes us, in everyday life and as researchers. We cannot access or contain it, know it or control it' (2015: 2). In a similar vein, Adam argues that studying 
the future poses major challenges because it lacks the tangible materiality needed for empirical study. This difficulty should not be taken as an excuse to place futurity outside the social science frame of reference. Rather, it needs to be acknowledged and understood in order to adapt our modes of inquiry (2009: 1).

Both Lyon and Carabelli and Adam note that some of the difficulties of studying the future emerge because of its intangibility. One way to 'adapt our modes of inquiry' to access and know the intangibility of the future is to consider the current and ongoing elaboration of interdisciplinary theories, methodologies, and analyses to engage (with) affect. Affect is variously described as elusive, excessive, non-rational and/or difficult to articulate through language (Massumi 2002, Clough 2002, Blackman and Venn 2010, Coleman 2012). It also refers to the relational forces through which entities human, non-human, environmental - are constituted, moved and transformed (e.g. see Coleman 2009, 2012, 2016a, Anderson 2014). In attempting to study the future then, it is helpful to make connections with work on affect that seeks to study the intangible.

Such a connection is also helpful because a number of social and cultural theorists have recently noted the affectivity of the future. For example, Vincanne Adams, Michelle Murphy and Adele E. Clarke argue that anticipation of the future is a 'defining quality of our current moment' in the West, and is a 'palpable' and 'affective state' (2009: 247). Ben Anderson has argued that anticipation operates affectively as it is 'deployed in liberal democracies to govern a range of events, conditions and crises' (2010: 779), while Brian Massumi (2005) has argued that pre- 
emption of the future characterises contemporary Western societies and modes of power, and operates through fear.

These examples highlight both the (im)materiality of affect, and the ways in which an affective temporality complicates or confuses linear temporality, so that the future is not (only or so much) a distinct and/or far off temporality, separate to the present (and past), but is (also) encountered, experienced and felt 'in' and as the present (Coleman 2012, 2016b). This work also explores the future in terms of the affects, emotions, feelings and sensations (such as alertness, vigilance, fear, and moods more generally) that it might elicit and organise. Such understandings of the future as affective and therefore provide means of developing methodologies and modes of inquiry to study the future.

Whilst not necessarily concerned with debates about affect per se, developments in visual and sensory sociology ${ }^{2}$ are also concerned with recognising the significance of the sensory and intangible to everyday life (for example, Mason and Davies 2009, Stewart 2007, Pink 2009, Coleman and Ringrose 2013). Sensory sociology - broadly conceived - aims to focus on what has tended to be bracketed out of sociological accounts of the world, and, relatedly, to recognise how the world is experienced in sensory ways. For example, John Law and John Urry note both that '[t]he fleeting, the ephemeral, the geographically distributed, and the suddenly proximate are of increasing importance in current senses of the social', and that current sociological methods are ill-equipped to deal with them (2004: 403). Lisa Adkins and Celia Lury describe a contemporary 'sensate empirical' (2009: 18), Les Back argues for an expansion of 'the sensory dimensions of sociological attentiveness' (2012: 28), and 
researchers such as Lata Mani (2013) and Kathleen Stewart (2007) experiment with interdisciplinary modes of communicating sensory experiences of being in and with the world. Indeed, many sensory methodologies draw and adapt from practices in art and design, appreciating that sociology does not have the monopoly on 'telling about society' (Becker 2007), and that non-textual methods and modes of dissemination are important in involving (human and non-human) participants and audiences in sociological research (Puwar and Sharma 2012).

Such arts-based methodologies are helpful in the development of a sensory sociology of the future in terms of their interest in the sensory and affective. Importantly, such methodologies have also been taken up to investigate temporality (for example, Back and Gunaratnam 2013), and futurity and potentiality more specifically (for example, the Pursuing Futures Research Group, University of Cardiff ${ }^{3}$ ). Lyon and Carabelli's research involved a series of arts-based workshops, including collage-making, improvised performances, and image elicitation, 'to enlarge the scope for understanding research participants' sense of the world and of themselves, past, present and future' (2015: 2).

A focus on young people and a commitment to participatory research ${ }^{4}$ can be identified in some of this arts-based work on the future. Indeed, Lyon and Carabelli reflect on how, in the literature on arts-based methodologies, young people are seen as particularly responsive to these methods, and as empowered through it. While they acknowledge the problems of such (over-)claims, they also found these methodologies productive in enabling young people to produce non-textual engagements with the future, and emphasising 'working with imagination to produce 
new ways of knowing' (2015: 4). In their work with teenage girls in an ex-mining town in south Wales, Gabrielle Ivinson and Emma Renold employed mixed methodologies that included photo-elicitation interviews, semi-structured and ethnographic interviews based on photographs taken by the participants, walking tours and film-making activities (2013: 373). They argue that these allow them 'to explore the affect associated with everyday practices through the multiple activities, rituals and routines that comprised the micro-intensities of everyday life', and offer their participants 'ways to experience, think and imagine futures differently from those afforded by the community's mining past' (2013: 374).

\section{Children of Unquiet}

As I have outlined, Karikis' Children of Unquiet project took place in 2013-2014 in the geothermal area of Tuscany known as the Devil's Valley. ${ }^{5}$ The area is said to have inspired Dante's descriptions of hell in his poem, 'Inferno' (1308-1320), and throughout the $18^{\text {th }}$ and $19^{\text {th }}$ centuries, experiments in extracting and harnessing the chemicals and energy in the area were conducted. In the early $20^{\text {th }}$ century, the first geothermal energy plant in the world was built in the village of Larderello, followed in the 1950s by the construction of utopian industrial villages, designed by the Italian modernist architect Giovanni Michelucci, to house five thousand workers and family members. The introduction of automated and remote-operation technologies into the power plant from the 1970s dramatically reduced the number of employees required in the plant, and has resulted in the villages being depopulated or abandoned (Karikis 2014b: 4). The power plant continues to produce geothermal energy - around $26 \%$ of energy in the region - and, in one narrative, can be understood as a success story; operating in the context of a global industry responding to energy demands in an 
environmentally sensitive and sustainable manner. However, at the same time, Karikis notes, "narratives of a failed social-economic project and of mass exodus have progressively dominated the local villages from where people migrate leaving behind their homes and a fractured local community' (2014: 4).

Initial discussions with the local communities led Karikis to identify that a prevalent aspect of the narrative of socio-economic failure about the energy plant concerned the future of children who were brought up in or around the workers' villages. For parents and their generation, the plant and the wider region offered younger people no future; instead their expectations and hopes for these children's future were for them to move away and find other homes and occupations. Karikis organised workshops with some of these children to explore their imaginations of the future. Through these, the children expressed ways of locating themselves within or orienting themselves to future possibilities of the site that differed from their parents' expectations and hopes. ${ }^{6}$

The workshops with the children involved different kinds of activities, including the children 'draw[ing] the village the way they imagine repopulating it and living there in the future', generating urban plans and being photographed contemplating the sites and sounds of the geothermal site ${ }^{7}$. These workshops produced six interlocking parts that compose the project, including the film introduced above. The film itself is composed of three chapters:

In the first chapter the children present an aural portrait of the place where they are growing up by singing the sounds of their surroundings: that is 
harmonizing with the powerful subterranean rumbles and singing along to the factory drones in the area. In the following chapter they congregate in the Modernist ruins to read philosophical texts about production, the industriousness of bees and love, while the closing chapter bursts with the noise of play and laughter as the children storm into the deserted village ${ }^{8}$ (see figures 1-3).

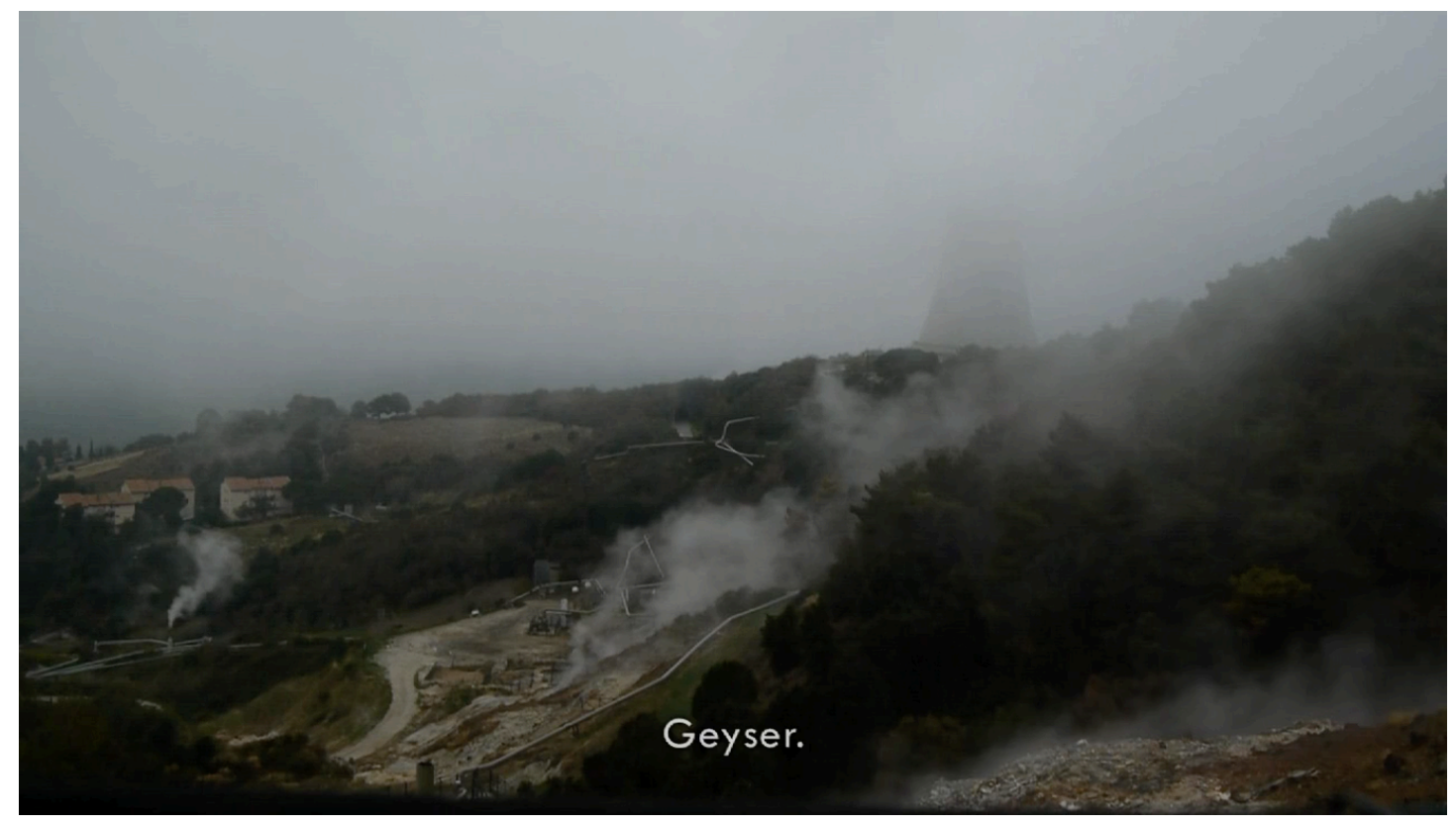

Figure 1: Screen shot from Children of Unquiet, chapter 1. 


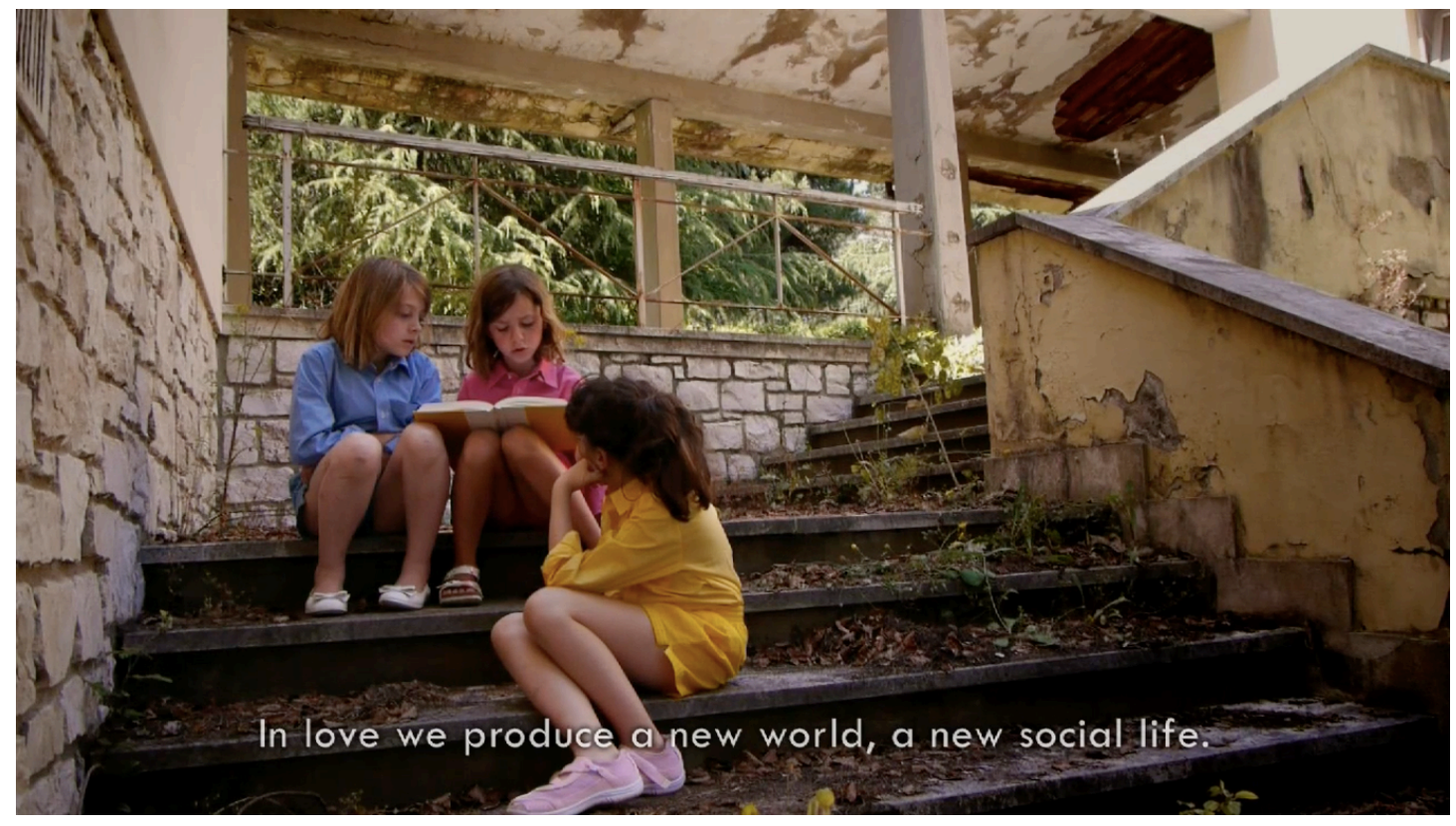

Figure 2: Screen shot from Children of Unquiet, chapter 2.

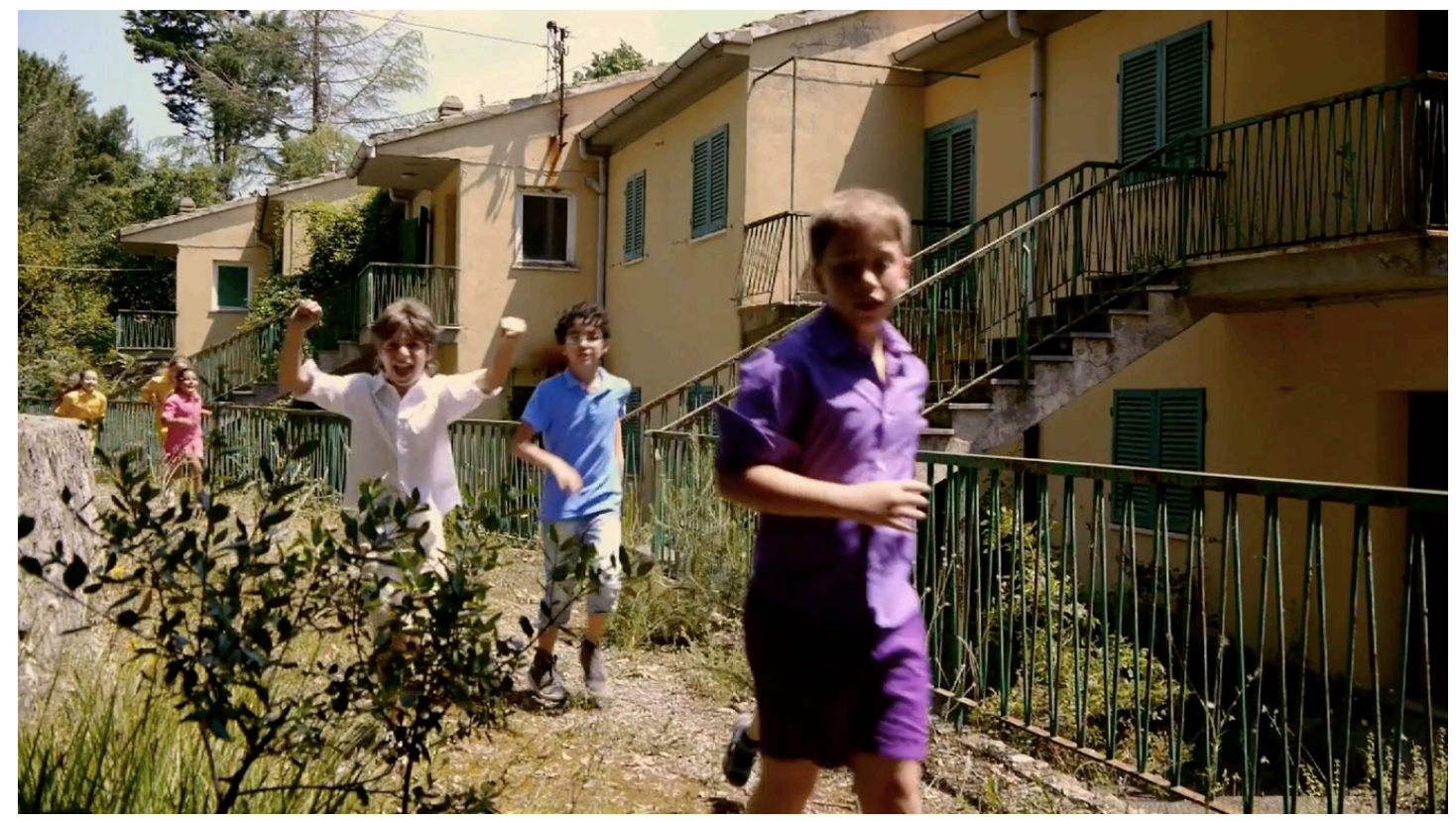

Figure 3: Screen shot from Children of Unquiet, chapter 3.

Building on the previous two chapters, it is the last one, then, that evokes the

'different possible, desired or imagined futures' to which Karikis points. 
It is important to recognise that Karikis is an artist and that Children of Unquiet was funded, devised and developed, and is screened and exhibited, in the context of the arts. It is thus necessary to note that Children of Unquiet is not intended to be a piece of sociological research in terms of the theoretical, political and ethical traditions from which it draws, the questions and methods it works through, and the arenas in which it is designed to be shown, discussed and evaluated. Nevertheless, it is productive to make connections between Children of Unquiet and the concerns, methodologies and modes of dissemination being developed in sensory sociology. For example, the workshops that Karikis organized and the modes of disseminating the project have connections with those developed in the research that I discuss above.

Further, both Children of Unquiet and the sensory sociology of the future discussed above operate through a commitment to the participation of local groups, and particularly hard to reach or marginalised groups. In Children of Unquiet, Karikis worked closely with communities, local organisations, government bodies, the factory and key individuals from within and around Larderello 9 . These children's futures are therefore understood as diminished or excavated. More especially, the project positioned the children at the centre of the work. In this way, those who were described as having no future were provided with a means to explore and articulate their relationship with the local area, and its possibilities.

In these senses, whilst not strictly a piece of sociological research, Children of Unquiet resonates with many of the concerns of the sensory sociology outlined above. Indeed, the connections between sensory sociology and Children of Unquiet that I am drawing here can be understood in terms of those set out by Mike Michael (2012) in 
an argument that seeks not to juxtapose sociology and speculative design, but rather to explore, 'what are the common byways along which they travel? Where are the junctures at which they touch? How can the engagements between these be rendered open, multiple, uncertain, playful?' (2012: 177). My argument here, then, is not so much that Children of Unquiet can or should be understood as a piece of sociological research (although I think this may be possible), nor that sensory sociology should necessarily involve arts-based methods or participatory research (although it often does). Rather, it is that in considering the development of a sensory sociology of the future, it is productive to examine the resonances and junctures between the attempts to engage the possibility and intangibility of the future in Children of Unquiet and in sociological research.

\section{Futurity, queer theory and the child}

In his consideration of the 'common byways' between speculative design and sociology, Michael explains that speculative design is interested in creating engagements with possible futures (rather than objects that fulfill a particular goal or purpose) (2012: 171). For example, he discusses how the aim of a 2009 exhibition of work by the interaction and speculative designers Anthony Dunne and Fiona Raby's, titled 'What if...', was to

probe our beliefs and values, challenge our assumptions and encourage us to imagine how what we call "reality" could be different. They help us see that the way things are now is just one possibility, and not necessarily the best one (Dunne and Raby, in Michael 2012: 172). 
Interestingly, noting how in the second chapter of the film the children read aloud philosophy, Karikis describes Children of Unquiet as 'a speculative project: what if there were no adults, and children unearthed books among the rubble in which they discovered something the previous generation did not? Enlightened by this discovery, how will they transform this place?' (Hardt and Karikis 2014: 16-18).

It is not coincidental that providing means through which to speculate on possible futures ${ }^{10}$ - in both the sociological research I have discussed and in Karikis' project is explored with and through children. The relationship between the child and the future is an intense one for a number of inter-related reasons. Nick Lee argues that while the notion of reaching a stable and secure end point of adulthood is troubled by adult life now being characterized by change and uncertainty (in the flexible and adaptable labour conditions required by neoliberalism, for example), childhood is nevertheless primarily understood in terms of a destination. As such, '[c]hildren's lives and activities in the present are still envisaged, in the main, as a preparation for the future' $(2001: 8)^{11}$. This intense relationship between the child and the future is, in part, because children or young people are often seen as those with most investment in the future, and thus with most to lose should the possibilities of the future not be open or attainable, but diminished.

As oriented to a destination, the child is seen as in the process of becoming. As Claudia Castenda puts it, there is a strong 'identification between the child and mutability', where 'what is distinctive about the child is that it has the capacity for transformation'; indeed, this capacity of transformation is more of 'a requirement', in that 'the child is never complete in itself' (2002: 2, see also Burman and Stacey 
2010). ${ }^{12}$ This transformative capacity of the child can be understood in terms of affect. In Anna Hickey-Moody's terms childhood is as 'an affective capacity or capacity to be affected, both positively and negatively' (2013: 282). Conceived in this way, the child is potential(ity), a capacity for transformation or becoming that is affective. The relationship between the child and futurity is thus also intense through this affectivity.

Recent debates in queer theory are helpful in further exploring the relationship between the child and futurity in terms of affect and potentiality ${ }^{13}$. For Lee Edelman, there is a need to give up on the future because of how, across American politics and popular culture, the future is collapsed into the figure of 'the Child"14. The Child comes to constitute 'the perpetual horizon of every acknowledged politics' (2004: 3), resulting in what he terms 'reproductive futurism'; a heteronormative understanding of the future as reproduced by and for the Child, which 'render[s] unthinkable, by casting outside the political domain, the possibility of a queer resistance to this organizing principle of communal relations' (2004: 2). In other words, for Edelman, reproductive futurism is heteronormative, and queerness is placed outside of the realm of reproductive futurism: as having no future. Important here is that Edelman's argument is premised on an adult understanding of the Child, and its temporality in particular; the Child is not a being in and of itself, but rather the logic of reproductive futurism operates through the mobilisation of the Child as destined towards an adult future. It is through this logic that Edelman suggests that those who are marked or identify as queer 'accept[...] and even embrac[e]' the 'ascription of negativity to the queer' (2004: 4). Queer theory should refuse the future, 'assert itself instead against futurity, against its propagation' (2004: 33). 
However, José Esteban Muñoz (2009) takes issue with Edelman’s argument, maintaining that while some may be able to turn away from it, the pull or appeal of the future remains important to many other people:

It is important not to hand over futurity to normative white reproductive futurity. That dominant mode of futurity is indeed "winning", but that is all the more reason to call on a utopian political imagination that will enable us to glimpse another time and place: a "not-yet" where queer youths of colour actually get to grow up (2009: 95-96).

It is not as straightforward as arguing that the children in Karikis' project are queer in the sense that Muñoz describes. However, if the queerness that Muñoz suggests is an attempt to "call on a utopian political imagination that will enable us to glimpse another time and place', there are 'common byways' to be drawn between Karikis' and Muñoz's work. Indeed, just as Karikis notes that it is necessary to enable the children to imagine different possible futures for Larderello, Muñoz does not want to turn away from the future, but to see that future as necessary:

The here and now is simply not enough. Queerness should and could be about a desire for another way of being in both the world and time, a desire that resists mandates to accept that which is not enough (2009: 96).

\section{Hope, potentiality, affect}


The interest in the possibility of a different future that both Karikis and Muñoz point to can be understood in terms of hope. For Edelman, the refusal of futurity is, at once, a refusal of hope. Hope 'reproduces the constraining mandate of futurism' through its 'insistence of [itself] as affirmation' (2004: 4). Hope is, in this sense, characterized as necessarily affirmative, and as necessarily a deferral to the (reproductive, successive) future $^{15}$. However, Muñoz offers an alternative understanding of hope; as that which is about 'an insistence on potentiality or concrete possibility for another world' (2009: 1). Whereas Edelman defines queerness in terms of negativity, Muñoz argues that 'queerness is primarily about futurity and hope'. Whereas Edelman defines the future in terms of the preservation of heteronormativity, Muñoz argues that '[q]ueerness is not yet here' (2009: 1).

In arguing that queerness is not yet here, Muñoz is not suggesting that the future is some far off time. Rather his understanding of futurity is developed through the potentiality of hope. For example, Muñoz explains his concept of hope as an 'affective structure[...] that can be described as anticipatory' (2009: 3). The anticipatory affectivity of hope is Muñoz's means of imagining a time other than the 'broken-down' here and now; an anticipation that he describes not in terms of a deferral to the future but as an illumination or animation: 'The anticipatory illumination [...] is a kind of potentiality that is open, indeterminate, like the affective contours of hope itself' (2009: 7, my emphasis). Hope here is potentiality; 'a certain mode of nonbeing that is eminent, a thing that is present but not actually existing in the present tense' (2009: 9, my emphasis). 
It is worth unpacking what Muñoz is arguing here about hope being a potentiality. First, hope as potentiality is an anticipation or illumination: it is that spark or flicker that might take us somewhere else, that might indicate the possibility of another kind of world. Second, hope is therefore open or indeterminate. The adventure that it might take us on is not something that can necessarily be known in advance. Third, as Muñoz indicates briefly, potentiality is affective: it is intangible and yet felt. Fourth, this potentiality exists within the present: it is a potential 'that is present' but that is not quite yet. Taking up these four interconnected aspects of hope as potential - as an anticipation, as open, as existing in the present, as affective - hope is actually here and now, is a potential that might be actualised in or from the present.

Such an understanding of hope is productive when considering the engagement with futurity in Children of Unquiet. For example, hope as potential is explored through working with children, who, as discussed above, can be conceived as both themselves affective potentiality and capable of imagining the affective potentiality of the future of the Larderello site. Hope as anticipation, as open and as in the present can also be thought through in terms of Karikis' explanation of the second chapter in the film as a speculative project: it is an engagement with the future that operates via exploring 'what if...?'. The books the children find in the abandoned workers' villages may spark or illuminate another possible world: 'how will they transform this place?' Karikis goes on to explain that,

I do not show how the site will change in the future; as an artist I am interested in finding the potential for change with and through the communities I 
collaborate [with]. Then it is up to them to define the exact reforms they wish to make (Hardt and Karikis 2014: 18) ${ }^{16}$.

Here, then, the future is not prescribed, but is in the present and open. Karikis' explanation frames the project as 'finding the potential for change' rather than necessarily actualizing that change. The future that is accessed in the present is left unfinished.

I have already indicated that in developing a sensory sociology of the future, and in considering the intense relationship between the child and the future, it is helpful to consider research on and with affect; here, affect is central to the ways in which the Children of Unquiet film engages futurity in terms of hope. While affect can refer to particular feelings and emotions - indeed, the philosophy that the children read in chapter 2 is in part concerned with love - it can also refer more broadly to forces, energy and atmospheres created between (human and non-human) bodies, spatialities and temporalities. This latter understanding of affect is especially pertinent to the structure, content and - at least for me - the affective experience of viewing the Children of Unquiet film.

For example, the take-over of the site in chapter 3 opens with shots of the abandoned villages along with the sound of bird song and the excited voices and calls of the children, which become increasingly louder (see figure 4). Anticipation is in the air. 


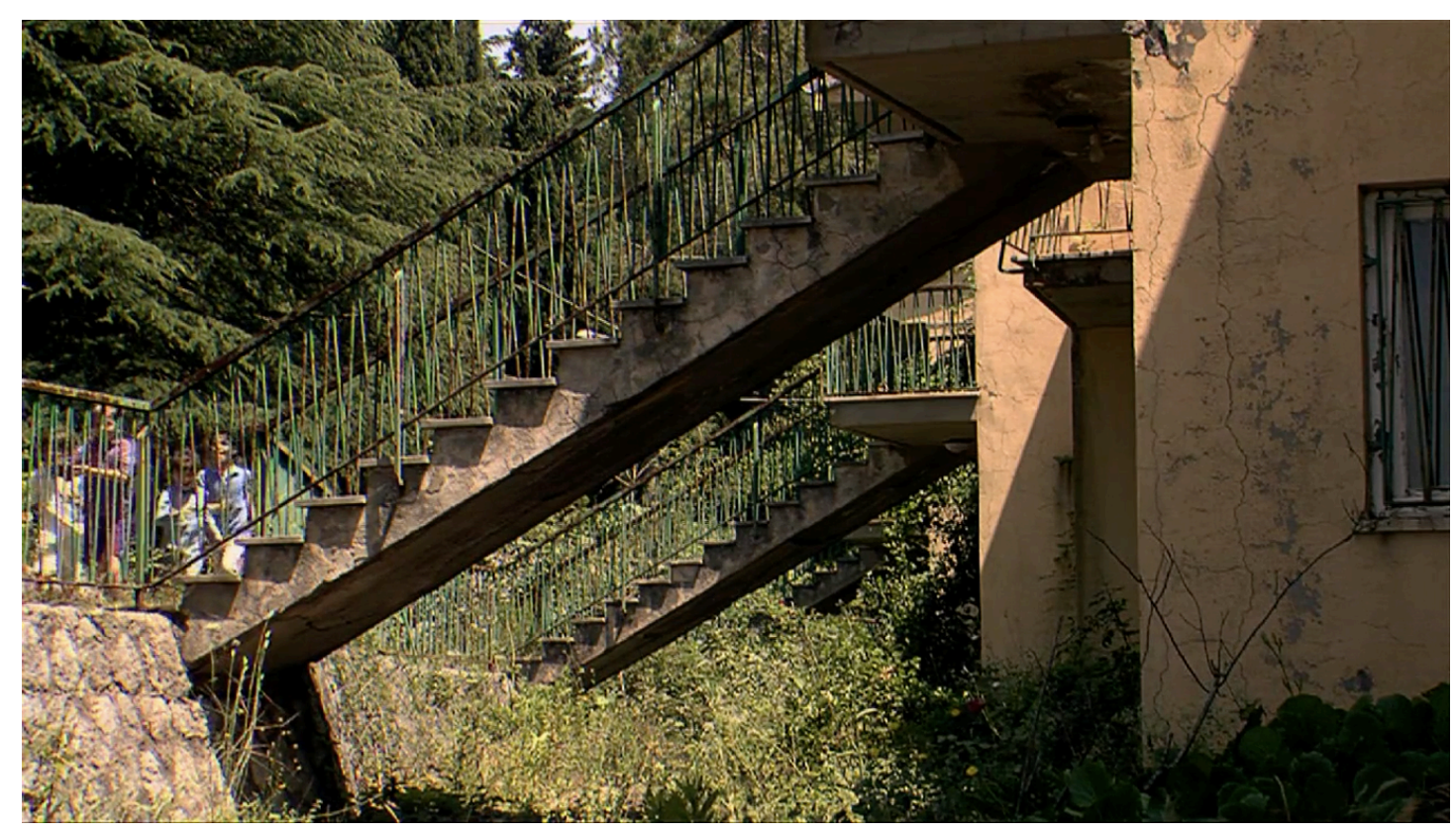

Figure 4: Screen shot of opening of Children of Unquiet, chapter 3.

These shouts and calls are slowly replaced with a chant - ooooooooooo - in several different pitches, as groups of children, dressed in bright pinks, purples, yellows, blues, and white, gather at various points around the site; outside domestic buildings, in the craters surrounded by the steam of the geothermal energy, lying on the grass or standing with their heads up against the pipes that carry the steam to the factory (figures 5-6). Something is about to happen. 


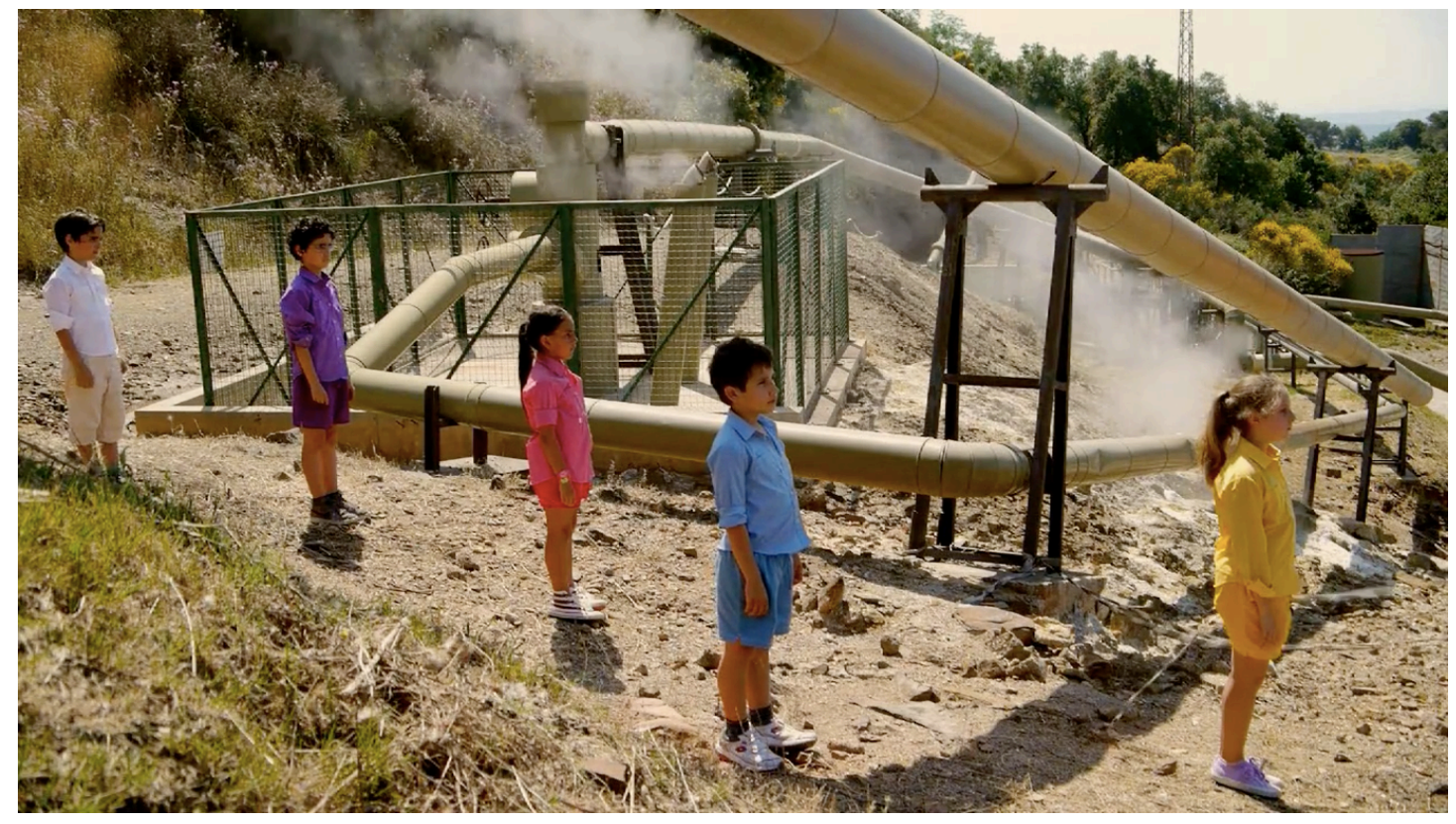

Figure 5: Screen shot of Children of Unquiet, chapter 3.

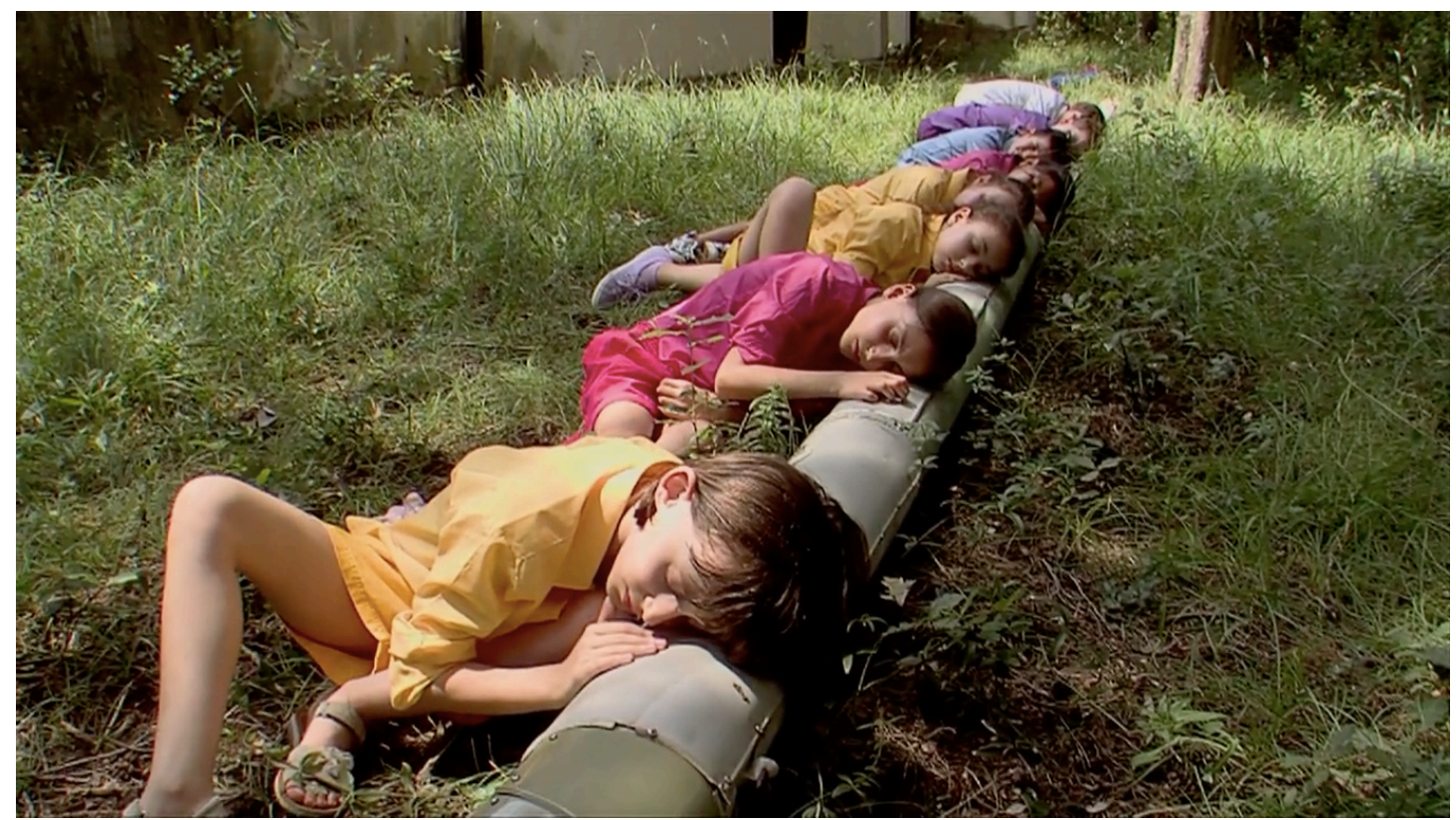

Figure 6: Screen shot of Children of Unquiet, chapter 3.

This harmonious chant gradually becomes more insistent, is joined by the hisssssss that evoke the steam and interrupted with shorter shouts - ' $h a !$ '. These sounds get 
louder, and images show the children playing football, and beginning to stamp their feet in time with the sound of their ' $h a$ !'s (figure 7).

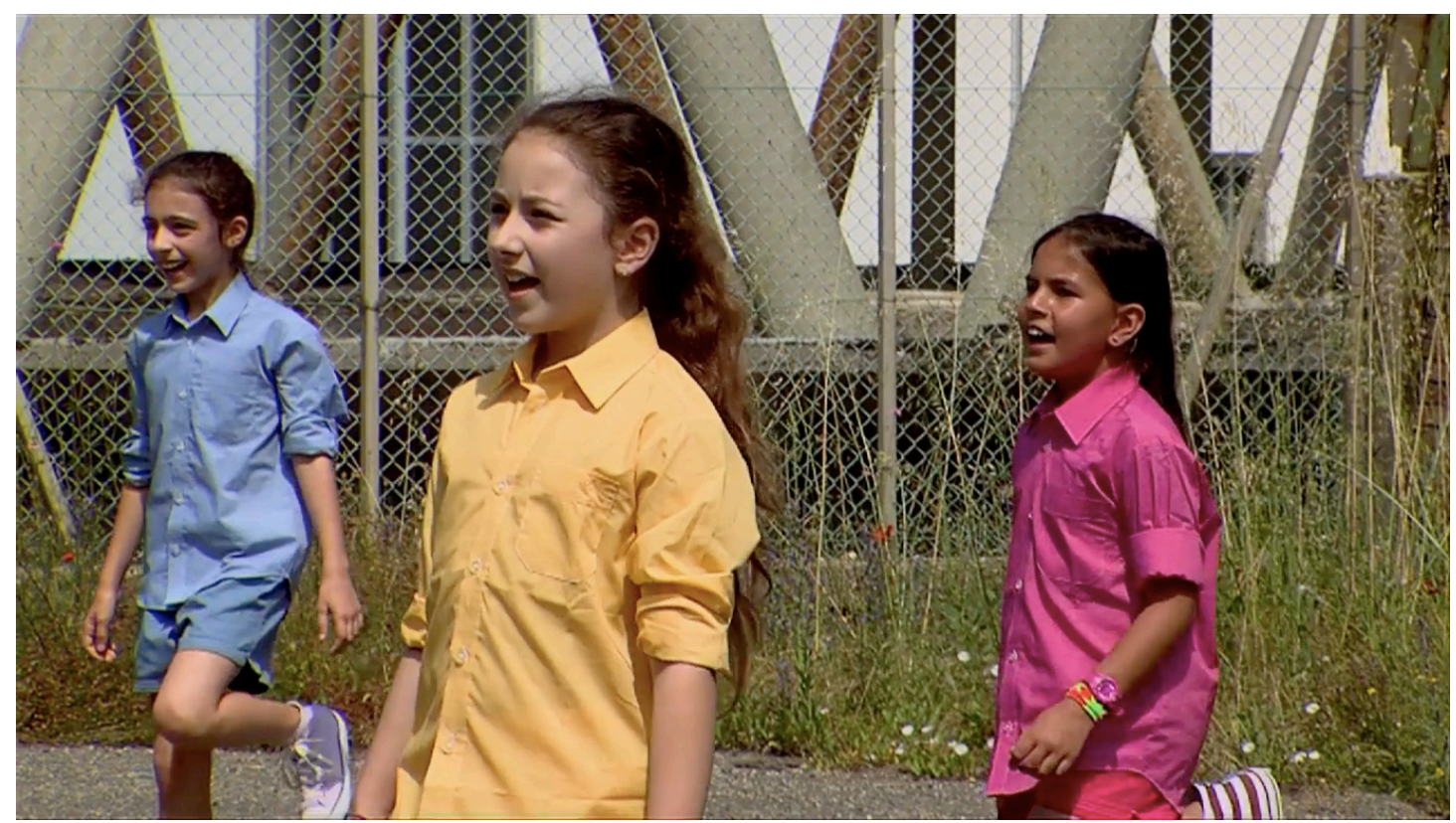

Figure 7: Screen shot of Children of Unquiet, chapter 3.

These images are joined by ones of the children playing (figure 8).

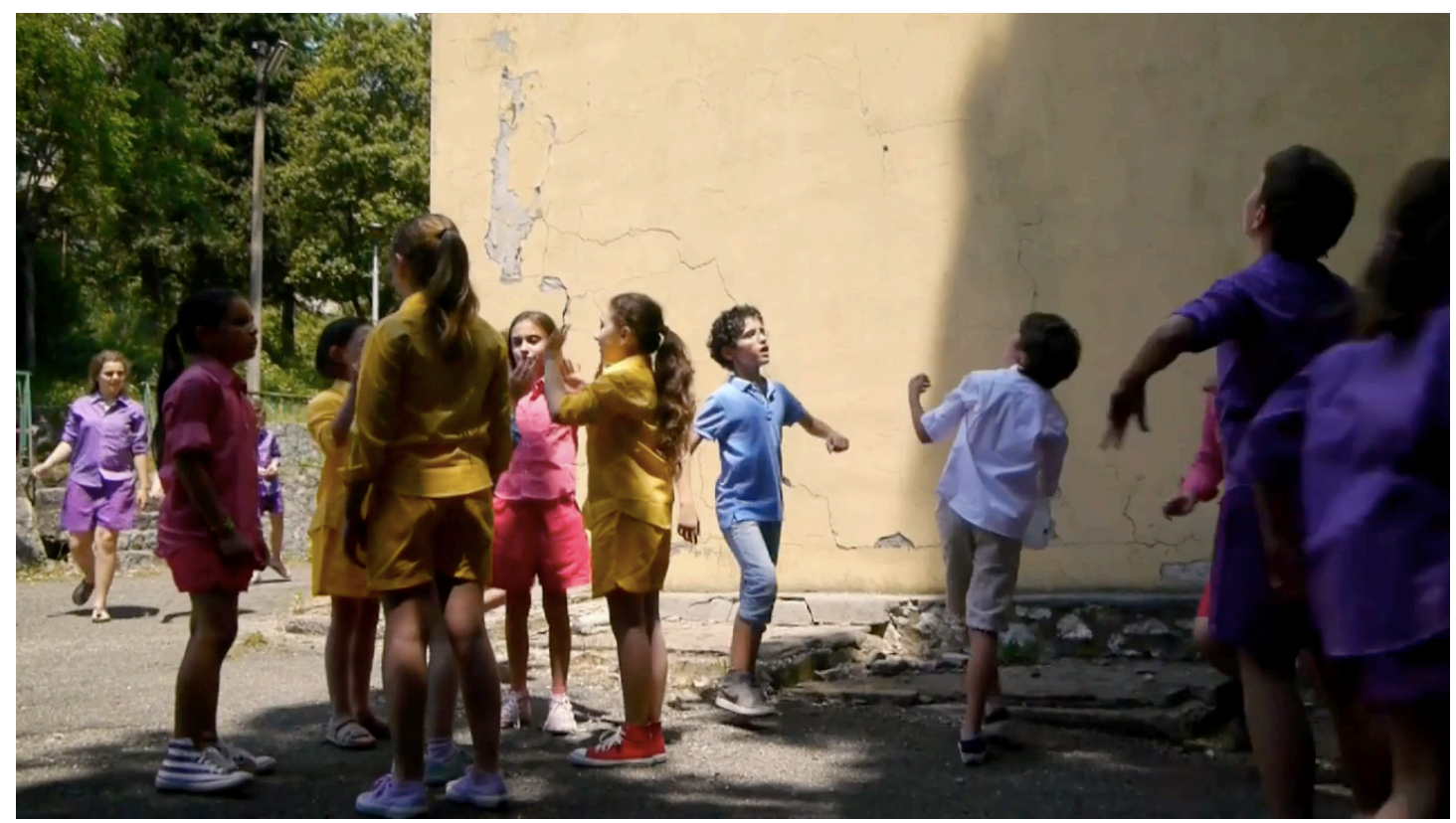


Figure 8: Screen shot of Children of Unquiet, chapter 3.

The film ends with a black screen over which the sound of children laughing lingers for several seconds.

It is notable, I think, that while the film indicates that something is about to happen, rather than reaching a crescendo or a final end point the take-over of the site through play and song fades out over the sounds of laughter. This 'ending' might be understood in terms of the becoming of the child - a process that is never complete (Hickey-Moody 2013). It might also be understood in terms of the potentiality of the future being in the present. The different possible, desired or imagined futures that are evoked in the film are not capable of being fully realized; instead, they are illuminated in the present as the possibilities of how the children might inhabit the site, and are up to the participants to continue to actualize. The film therefore operates in terms of hope as an affective potentiality in the present. Such an indication of futurity in the film can, further, be understood in terms of the notion of speculative methods that I introduced above, where the aim is not so much to produce finished objects or findings, but rather to probe how the world may be different.

As is clear, sound is a particularly significant way in which the film operates affectively, in that it creates an atmosphere of anticipation and of potentiality. Here, then, the 'aural portrait' of the site that Karikis describes can be understood as, in Lyon and Carabelli's terms (2015: 10), a 'process' and 'tool' through which to reveal and stimulate these children's possible futures. Furthermore, for David Oswell, sound is a crucial means to address the problem of infancy in and to politics. Politics usually 
rests (implicitly or explicitly) on 'the endeavor of responsible, rational, political agents', who are both mature and human (2009: 2). Such an understanding of politics can be traced back to Aristotle, for whom a distinction between speech or language, and voice designates humans as divergent from animals, and posits politics as the 'articulation of reason [through speech] by men within an organised political unit' (2009: 5). This understanding of politics raises questions for how those who are (seen as) not able to speak are and may be positioned and involved in a political project; children, along with racialised, gendered, sexualized and classed others, are an ‘inclusive exclusion' or constitutive outside to a politics based on speech (2009: 8).

Oswell's response to this positioning of children in relation to politics is to focus not only on the content or meaning of speech or language, but also on its sensation and sensory-ness; sound or 'sounding' is something 'immediate', a 'physical connection' (2009: 10), or 'resonance across people, things, technologies and nature' (2009: 3). Focusing on sound in this way enables a consideration of

the attractions and repulsions, the associations and disassociations, and the patterns and structures of those sounds with respect not simply to those that utter the sounds but also other sounds within fields of interaction and other materialities, objects, technologies and subjects (2009: 12).

Such a consideration seems especially pertinent to an understanding of how sound functions in the Children of Unquiet film to affectively indicate the potentiality of the future. For example, the children 'sing[...] the sounds of their surroundings'; this is not only an articulation or making into speech of non-human sounds, but also, as 
Karikis explains, a 'harmonizing' with the natural and cultural sounds of the site - the bees and birds, the geysers both as they erupt from the ground and as the steam is funneled through pipes to the factory, the water that drips from leaky taps. Here, 'materials, objects, technologies and subjects' (Oswell 2009: 12) connect, resonate and interact. Further, as I have discussed in terms of the potentiality of futurity and of hope, this interaction of materialities, media, spatialities and temporalities, hint of a not-yet. In Oswell's terms, '[t]hose voices and those noises that support politics in terms of how things might become are not the repressed rumbling underbelly of politics; they are its generative and generational core' (2009: 16).

\section{A sensory sociology of the future}

In this article, I have considered the development of a sensory sociology of the future in light of an increasing interest in sociology and other social sciences in both the future and the intangible, sensory and affective dimensions of social life. I have focused especially on the methodological problem of researching the future, and suggested that both sensory methodologies and work on affect are particularly productive for grasping and engaging the intangibility of the future. In line with recent research on futurity that draws on art and design, I have analysed Children of Unquiet as a means to make connections between projects on the future developed through different traditions and contexts. To conclude, I indicate some possible coordinates that seem to me to characterise the contours and concerns of an emerging sensory sociology of the future.

One of these co-ordinates involves participation; the social scientific and artistic attempts to engage futurity discussed here operate through participatory 
methodologies, including workshops involving a number of research participants. While orientations to, imaginations of and engagements with the future may be individual(ised) and/or produce outputs that are associated with distinct individuals, they work through collective efforts; that is, as noted above, across and between people, spatialities, temporalities, materials, media, technologies. Relatedly, the question of outputs is raised; what are the most appropriate means to circulate and disseminate (sociological) research where not only textual data is generated, but also media and materials such as films, photographs, collages, performances, objects, devices, board games? Lyon and Carabelli's and Ivinson and Renold's modes of dissemination include exhibitions, performances and websites, indicating that sociological outputs are necessarily moving 'beyond-text' (see also Puwar and Sharma 2012). This is an especially important issue for social research that is concerned with the intangible and affective. Further thinking and experimentation is required to disseminate the atmospheres, sensations and affects that have been discussed here. How, for example, might the sounds/soundings that Oswell and Karikis indicate are important to a politics of the not-yet be disseminated?

Of particular significance to the work discussed in this article has been the focus on and participation of children. As I have discussed, this focus on children is due to their association with becoming, affect and the future, and with visual and sensory methodologies. However, while children have a close association with the future, it is also worth returning to Muñoz's argument regarding the importance of the potentiality of hope and futurity to queer projects; I would suggest that it is possible and important - to expand 'queer' to include a range of minoritarian positions and politics. What social groups or collectivities are the focus of concern in failure 
narratives about a diminished future? Who are positioned as especially important in terms of guaranteeing or working towards a better future? Who feels the future? Such questions have been addressed here through a focus on children, who I have suggested is positioned - both positively and negatively - as an affective capacity that is positioned and experiences the future particularly intensely. More broadly, such questions are important to examine the ways in which power works temporally and affectively to make and re-make difference and inequality through the image of a better, or diminished, future (see Coleman 2012).

A further co-ordinate is interdisciplinarity. Projects that draw on, adapt and contribute to different disciplines and contexts seem to be particularly apposite for studying the intangibility of the future. This point is important in terms of the sensory arts- and design-based methodologies that I have discussed, and the work on affect, which itself draws on interdisciplinary understandings of the non-representational, intensive and intangible. It is also important in terms of the emergence and development of queer theory, which takes up potentially diverse approaches (e.g. from literary criticism, film studies, feminist theory and critical race studies) to critique and destablise gender and sexual norms. Such an engagement with interdisciplinarity may also demonstrate a 'logic of ontology', that is, as Andrew Barry, Georgina Born and Gisa Weszkalnys (2008) put it, 'an orientation towards effecting ontological change' in terms of the objects, subject and relations at stake in particular disciplines (2008: 25). Interdisciplinary work, they argue, 'has the potential to be inventive' (2008: 25):

The notion of invention points to the openness of the contemporary historical situation. An invention can be understood as the introduction of a type of 
novelty into a particular domain, one that cannot be explained away as the consequence of pre-existing factors or forces, and which serves to protend and open up the space of future possibilities (2008: 25-26).

Indeed, to make explicit an argument made here, a sensory sociology of the future might be interested not only in documenting orientations or imaginations of the future, but also in probing, provoking, stimulating them. This would be to understand a sensory sociology of the future in terms of speculative, performative and enactive (Law and Urry 2004), and/or inventive (Lury and Wakeford, see also Coleman 2016c) methodologies. For Law and Urry, for example, it is important to ask whether it is 'possible to imagine social science method as a system of interference (we draw the term from Donna Haraway) for working towards and making particular forms of the social real while eroding others?' (2004: 397). In this sense, in Karikis' words, the Children of Unquiet project can be understood as 'a form of resistance to the narratives that dominate their lives that claim that the children will have to leave the area to find a better future elsewhere' (2014: 20); that is, an erosion of a socioeconomic world in which such narratives come to be possible (through making people redundant from work) and dominant (through there being no hope in the future). Children of Unquiet provides the conditions through which to speculate (on) how hope in the future might be illuminated in the present. While it is not an answer to the problems of Larderello and its surrounding area - it is temporary and partial - it is concerned with speculating on 'what if...'. It introduces 'a type of novelty into a particular domain, [...] which serves to protend and open up the space of future possibilities (Barry et al 2008: 25-26), and is 'oriented towards making a difference' (Lury and Wakeford 2012: 11), and hence is inventive. 
Inventive methods, Celia Lury and Nina Wakeford explain, 'are able to grasp the here and now in terms of somewhere else, and in doing so - if they can also change the problem to which they are addressed - they expand the actual, inventively' (2012: 12, reference omitted). My discussion of Children of Unquiet in relation to Muñoz's conceptualization of hope indicates that the film might be understood in terms of this definition of inventiveness. Beginning with the problem of how the children of Larderello are cast as having 'no future', it operates as a platform through which to address and change the problem, 'expand[ing] the actual, inventively' through encouraging the children to imagine and speculate on and with the future otherwise, in a temporary fashion in the present, and hence in/of the actual. Indeed, Muñoz's statement that hope in the future is necessary because ' $[\mathrm{t}]$ he here and now is simply not enough' also indicates that the relationship between the present, or actual, and future, or virtual, is crucial; as I have discussed, hope is an affective, open potentiality that exists in the present. The question is therefore how to access, cultivate and exploit this potentiality in order for a different, better future to emerge. An important co-ordination of an emerging sensory sociology of the future is thus to explore and create the conditions through which 'things might become'.

\section{Acknowledgements}

Thanks to Mikhail Karikis for his generosity in engaging with my interest in his work, and to Yasmina Reggard and Michael Guggenheim for collaborating on the We Can't Be There: Emergency Provisions for (Un)Anticipated Futures series, where the Children of Unquiet film was screened and discussed. Thanks also to David Oswell 
for participating in that discussion, and for recommending references on childhood. Finally, thanks to those, past and present, on the MA Visual Sociology at Goldsmiths, who have contributed immensely to my argument here in ways that they may or may not recognise. This paper emerged from the ESRC Seminar Series, Austerity Futures: Imagining and Materialising the Future in an 'Age of Austerity', (grant number $\mathrm{ES} / \mathrm{J} 021512 / 2)$.

\section{Bibliography}

Adam, B. (2004) Time, Cambridge: Polity.

Adam, B. (2009) 'Future Matters: Challenge for Social Theory and Social Inquiry',

Conference Paper: http://www.cardiff.ac.uk/socsi/resources/Sardinia.pdf, accessed $9^{\text {th }}$ September 2015.

Adams, V., Murphy, M. and Clarke, A. E. (2009) 'Anticipation: technoscience, life, affect, temporality', Subjectivity, 28(1): 246-265.

Adkins L. (2008) 'From Retroactivation to Futurity: The End of the Sexual Contract?', Nora: Nordic Journal of Feminist and Gender Research, 16: 182-201.

Adkins, L. (2014) 'Luc Boltanski and the Problem of Time: Notes towards a Pragmatic Sociology of the Future', in S. Susen and B.S. Turner (eds), The Spirit of Luc Botlanski: Essays on the "Pragmatic Sociology of Critique, London: Athlone Press: 517-538.

Adkins, L. and Lury, C. (2009) 'Introduction: What is the Empirical?', European Journal of Social Theory, 12(1): 5-20.

Anderson, B. (2010) 'Preemption, Precaution, Preparedness: Anticipatory Action and Future Geographies', Progress in Human Geography, 34(6): 777-798.

Anderson, B. (2014) Encountering Affect: Capacities, Apparatuses, Conditions, 
Farnham: Ashgate.

Back, L. (2012) 'Live Sociology: Social Research and its Futures', The Sociological Review, 60, S1:18-39.

Back, L. and Gunaratnam, Y. (2013) Every minute of every day, http://everyminuteofeveryday.org.uk, accessed $1^{\text {st }}$ July 2016.

Barry, A., Born, G, and Weszkalnys, G. (2008) 'Logics of Interdisciplinarity', Economy and Society, 37(1): 20-49.

Becker, H. (2007) Telling About Society, Chicago: Chicago University Press.

Bergold, J. and Thomas, S. (2012) 'Participatory Research Methods: A

Methodological Approach in Motion', Forum: Qualitative Social Research, 13(1), Article 30: http://www.qualitative-

research.net/index.php/fqs/article/view/1801/3334\#g2, accessed $9^{\text {th }}$ September 2015.

Berlant, L. (2011) Cruel Optimism, Durham, NC and London: Duke University Press.

Blackman, L., and Venn, C. (2010) “Affect.” Body and Society, 16(1): 7-28.

Brown, N. and Michael, M. (2003) 'A Sociology of Expectations: Retrospective

Prospects and Prospecting Retrospectives', Technology Analysis and Strategic

Management,15(1): 3-18.

Burman, E. and Stacey, J. (2010) 'The Child and Childhood in Feminist Theory', Feminist Theory, 12(1): 227-240.

Castenada, C. (2002) Figurations: Child, Bodies, Worlds, Durham and London: Duke University Press.

Clough, P. T. (2000) Autoaffection: Unconscious Thought in the Age of

Teletechnology, Minneapolis: University of Minnesota Press.

Coleman, R. (2009) The Becoming of Bodies: Girls, Images, Experience, Manchester: Manchester University Press. 
Coleman, R. (2012) Transforming Images: Screens, Affect, Futures, London and New York: Routledge.

Coleman, R. (2016a) 'Affect', in renée c. hoogland (ed.) Gender: Sources,

Perspectives, and Methodologies. Macmillan Interdisciplinary Handbooks: Gender.

Farmington Hills MI: Macmillan, pp. 15-26.

Coleman, R. (2016b) ‘Austerity Futures: Debt, Temporality and (Hopeful) Pessimism as an Austerity Mood', in New Formations, 87: 83-101.

Coleman, R. (2016c) 'Developing Speculative Methods to Explore Speculative Shipping: Mail art, Futurity, Exchange', in Marsha Rosengarten, Martin Savransky and Alex Wilkie (eds.) Speculative Research: The Lure of Possible Futures, London and New York: Routledge.

Coleman, R. and Moreno Figueroa, M. (2010) 'Past and Future Perfect? Beauty, Affect and Hope', Journal for Cultural Research, 14(4): 357-373.

Coleman, R. and Ringrose, J. (eds) (2013) Deleuze and Research Methodologies, Edinburgh: Edinburgh University Press.

Edelman, L. (2004) No Future: Queer Theory and the Death Drive, Durham, NC and London: Duke University Press.

Hardt, M. and Karikis, M. (2014) 'In conversation about love' in Children of Unquiet: The Film, catalogue, London: future perfect: 8-23.

Hickey-Moody, A. (2013) ‘Deleuze's children', Educational Philosophy and Theory, 45(3): 272-286.

Ivinson, G. and Renold, E. (2013) 'Subjectivity, Affect and Place: Thinking with Deleuze and Guattari's Body without Organs to Explore a Young Girl's Becomings in a Post-Industrial Locale', Subjectivity, 6(4): 369-390. 
James, A. and Prout, A. (1997) 'Re-repesenting Childhood: Time and Transition in the Study of Childhood', in James, A. and Prout, A. (eds.) Constructing and Reconstructing Childhood, London and New York: Routledge.

James, A., Jenks, C. and Prout, A. (1998) Theorising Childhood, Cambridge: Polity. Karikis, M. (2014) 'Preface', in Children of Unquiet: The Film, catalogue, London: future perfect: pp. 4-7.

Karikis, M. (n.d.) http://www.mikhailkarikis.com, accessed $1^{\text {st }}$ July 2016.

Lazzarato, M. (2011) The Making of the Indebted Man, Los Angeles: Semiotext(e). Law, J. and Urry, J. (2004) “Enacting the Social”, Economy and Society, 33(3): 390410.

Lee, N. (2001) Childhood and Society, Maidenhead: Open University Press. Lury, C. and Wakeford, N. (2012), 'Introduction: A Perpetual Inventory', in (eds.) Inventive Methods: The Happening of the Social, London: Routledge: pp. 1-24. Lyon, D. and Carabelli, G. (2015) 'Researching Young People's Orientations to the Future: The Methodological Challenges of Using Arts Practice', Qualitative Research, online first: $19^{\text {th }}$ May 2015.

McCormack, D. (2014) Refrains for Moving Bodies: Experience and Experiment in Affective Spaces, Durham NC: Duke University Press.

Mani, L. (2013) The Integral Nature of Things: Critical Reflections on the Present, London and New York: Routledge.

Mason, J. and Davies, K. (2009) 'Coming to our Senses? A Critical Approach to Sensory Methodology', Qualitative Research, 9(5): 587-603.

Massumi, B. (2005) 'The future birth of the affective fact', Conference Proceedings: Genealogies of Biopolitics: http://browse.reticular.info/text/collected/massumi.pdf, accessed 14 July 2011. 
Michael, M. (2012) "De-signing the object of sociology: Toward an "idiotic" methodology", The Sociological Review, 60(S1), 166-183.

Mische, A. (2009) 'Projects and Possibilities: Researching Futures in Action', Sociological Forum, 24(3): 694-704.

Muñoz, J. E. (2009) Cruising Utopia: The Then and There of Queer Futurity, New York and London: New York University Press.

Nowotny, H. (1994) Time: The Modern and Postmodern Experience, Cambridge: Polity.

Oswell, D. (2009) 'Yet to Come? Globality and the Sound of an Infant Politics', Radical Politics Today, 1(1): 1-18.

Oswell, D. (2013) The Agency Of Children: From Family to Global Human Rights, Cambridge: Cambridge University Press.

Pink, S. (2006) The Future of Visual Anthropology: Engaging the Senses, London and New York: Routledge.

Pink, S. (2009) Doing Sensory Ethnography, London: Sage.

Puwar, N. and Sharma, S. (2012) 'Curating Sociology', in Back, L. and Puwar, N. (eds.) Live Methods, Oxford: Blackwell.

Stewart, K. (2007) Ordinary Affects, Durham and London: Duke University Press.

\footnotetext{
${ }^{1}$ A trailer for the film can be viewed at:

http://www.mikhailkarikis.com/2015/07/20/video-children-of-unquiet/, accessed $9^{\text {th }}$ September 2015.
} 
${ }^{2}$ In the rest of this article, I use the term 'sensory sociology' to make the connection between the sensory and affective qualities of futurity. See Mason and Davies (2009) for one discussion of the relationship between visual sociology and sensory sociology. ${ }^{3}$ http://pursuingfutures.org, accessed $8^{\text {th }}$ October 2015.

${ }^{4}$ On participatory research, see for example Bergold and Thomas (2012).

${ }^{5}$ Information in this section is from: Karikis (2014), Karikis' webpages on the project (http://www.mikhailkarikis.com/category/all-projects/children-of-unquiet/, accessed $2^{\text {nd }}$ September 2015), Societa Chimica Larderello website (http://www.scl.it, accessed $2^{\text {nd }}$ September 2015), Enel Green Power website (https://www.enelgreenpower.com/en-GB/, accessed $2^{\text {nd }}$ September 2015), conversation between Karikis, Oreet Ashery, David Oswell and Rebecca Coleman as part of the We Can't Be There: Emergency Provisions for (Un)Anticipated Futures series, ICA, $24^{\text {th }}$ January 2015, and informal discussions with Mikhail Karikis.

${ }^{6}$ It is important to note here that it is the parents who identified the children as having no future, while the children themselves can imagine futures in the area. I return to this point below.

${ }^{7}$ See: http://www.mikhailkarikis.com/2015/07/20/photo-series-children-of-unquiet/, accessed $9^{\text {th }}$ September 2015 .

${ }^{8}$ From: http://www.mikhailkarikis.com/2015/07/20/video-children-of-unquiet/, accessed $9^{\text {th }}$ September 2015.

${ }^{9}$ The participatory aspect of Children of Unquiet and its emphasis on a specific site also runs through some of Karikis' other works, including Ain't Got No Fear (2016), The Endeavour (2015) and Sounds from Beneath (2011-2012).

${ }^{10}$ My intention here is not to collapse speculative design into what Karikis describes as the 'speculative project' of Children of Unquiet, nor into the sensory sociological 
work on futures discussed above, but rather to explore the 'common byways' between such work. I also recognise that I mobilise a range of potentially 'slippery' terms in this paper - e.g. 'resonance', 'byways' 'co-ordinates'. In some ways, this is because of the intangibility or slipperiness of futurity that I am interested in here. This style of writing also draws on the some of the ways in which affect is grasped and discussed in interdisciplinary academic literature, where style can be an attempt to put to work the changing and mobile nature of the subject at hand.

${ }^{11}$ See James and Prout (1997) for an argument that it is the present of childhood that requires attention.

${ }^{12}$ Lee's point that childhood is often conceived as a period of transition indicates a distinction between the child as becoming and the adult as being. However, such a distinction is increasingly untenable, both in terms of the uncertainty of adulthood, which positions adulthood as well as childhood as a state of becoming, and also through the emphasis placed on children's agency, which demands children are understood and treated as beings (James, Jenks and Prout 1998, Oswell 2013). ${ }^{13}$ Turning to this work helps, I think, to indicate what is at stake in the sensory sociological work of Lyon and Carabelli and Ivinson and Renold I have already discussed, in terms of participation and an engagement with the future, as I go on to discuss.

${ }^{14}$ It is worth noting that in Edelman's argument, it is the figure of the Child that is at stake, rather than 'real' children. However, as Burman and Stacey (2010) point out, making and maintaining this distinction is difficult.

${ }^{15}$ On hope as deferral to the future, see also Berlant (2011); on how hope might be located in the present, see Coleman (2012) and Coleman and Moreno Figueroa (2010). 
${ }^{16}$ This may be one instance where the byways between sociology and this art project diverge; participatory research, for example, is most often concerned with producing research that can be ethically embedded in the social worlds of the participants once the project is over. It is also worth noting the role of philosophy in Karikis' film, where it acts as a found object that the children learn (in the correct way) and put to work. Participatory research, and sociological research on children more broadly, may well emphasise and work with the knowledges that the participants already have. Thanks to David Oswell for elucidating this point to me. 